\title{
From Adjusting to Rebuilding Police Institutions
}

\author{
Tibor Kozma*
}

\begin{abstract}
This article is intended for academics, think tanks and practitioners dealing with modern policing. The scope of the article is intentionally wide, and gives a general overview of issues involved, with minor adjustments, up to large-scale reestablishment of police institutions. The author aims to provide useful guidance to those who are in charge of conducting any police capacity building related activities. No matter the scale of the envisaged change, general background knowledge on police is essential in order to understand the implications of change.
\end{abstract}

Keywords: Police reform, capacity building, law enforcement, police organization

Everything is subject to change; many philosophies describe very well the dynamic nature of society. However, not only societies undergo change, but all its sub-elements, including the police. To provide a safe and secure environment the police should also observe, learn and adapt. Adaptation is a frequently observed institutional reaction but it does not go beyond a certain scale. If we would set up a scale measuring change as it occurs in police institutions beyond a regularly occurring adaptation, the first mark would be Adjust, the second Reform and the third Rebuild. In this regard, adjusting is more than a minor correction, may not take place often and, in an idealistic situation, one can observe such actions not more than once every few years. This activity is internally conducted by top professional police leaders who are in charge of planning, approving and executing. For instance, this may involve establishing a new team or a new unit within a department. In case of adjustment, there is no shocking or provoking event - I would argue that this is part of the organic institutional refreshing mechanism.

Reform, as next on the scale, is a much larger action, occurring perhaps just once in a decade. One of the significant differences in comparison with the adjustment phase is that police reform may be politically led. Sometimes it is also related to a change in po-

\footnotetext{
Since December 2010, LTC Tibor Kozma has served as a Police Liaison Officer in the West Africa Integrated Operations Team/Africa Division II, United Nations Department of Peacekeeping Operations. In this capacity he is in charge of strategic and key operational police, law enforcement related issues to UNMIL, UNOCI and West Africa sub-region. LTC Kozma has served 22 years as a professional police officer in Hungary and abroad for the United Nations and the European Union in post-conflict international police missions. LTC Kozma is a graduate of the Hungarian National Police Academy and the French Police Academy, l'École Supérieure des Officiers de Paix, Nice. LTC Kozma also holds a Masters Degree in Law from the University of Law in Debrecen, Hungary, and a Masters Degree in National and International Defense and Security Policy from the Zrinyi Miklos Hungarian National Defense University. $\mathrm{He}$ is currently writing his $\mathrm{PhD}$ dissertation on European Law Enforcement Models. He has been invited to deliver lectures in Hungary, Bosnia and Herzegovina, Kyrgyzstan, Croatia, Germany and the Czech Republic. He has published many articles on police, border management, law enforcement, peacekeeping and crisis management.
} 
litical administration. It could also be an institutional reaction to a shocking event after a long time ignored adjustment or a significant modernization meant to provide institutional solutions to various internal and external security related challenges. In this category, the change is well pronounced, supposedly well communicated and should aim for the mid to long-term. For instance, under police reform many modern police witnessed the establishment of a new (elite) police service in charge of organized crime, counterterrorism, high-profile crimes, etc. However, the scope of reform may likely go beyond and can even include merging police services into one single service, as was the case in Luxemburg (2000), Belgium (2001) and Austria (2005) when the former national gendarmerie service was merged into one single police service. Police reform requires thorough governmental planning, parliamentarian oversight and the adoption of a new police law. In some cases, such police reform occurs hand in hand with larger sectorial reforms either in tandem with the security sector or with the rule of law sector.

The rebuilding of a police service is inherently very different. Rebuilding almost always follows a war (armed) crisis or a total collapse and disintegration of the police institution. Unfortunately, there are several recent examples of this, many, but not exclusively, on the African continent. We could cite significant rebuilding case studies from West Africa, the most advanced and successful of which occurred in Sierra Leone. In all cases the state authority was not and could not be the driving engine of police rebuilding; rather, there was always the need for a strong, external partner to guide, foster and assist the host nation throughout the process. That could be based on bilateral or multilateral work partnering with states, as was the case with the generation of the new Palestine Police Service. In other cases, the driving engine could be a non-state actor, such as the United Nations (UN), the European Union, the African Union, the Organization for Security and Co-operation in Europe, or, to a lesser extent, some sub-regional institutions. Due to its nature, rebuilding is the most time and resource-consuming exercise. Case studies show that, at a minimum, a decade of constant external influence and activity is needed to generate a new police service from the ground up. Most of the cases required between 15 to 20 years, such as rebuilding the police in Bosnia and Herzegovina, which took almost two decades to complete. However, in some cases not even two decades are enough. The financial, infrastructural-material and human resources of a police rebuilding process may require a vast and long-lasting budget. The situation can be even more complex and add further challenges to an ongoing police capacity building operation, such as the case in Ivory Coast during the post-election crisis from November 2010 to April 2011, where unexpected political and armed conflict hampered the previously achieved results and, due to deep crisis, law enforcement institutions again suffered total disintegration. In some other cases, such as Somalia, the placement of the first cornerstone of the new police institution is lagging behind, thus the preparation of the rebuilding process (including the full scale of state authorities) may require not decades, but rather generations. 
Some rare cases of police rebuilding may not be directly connected to a crisis situation, but rather to a total change of the political climate. The establishment of the Catalonian Police is worth citing as a good case study, among other examples. ${ }^{1}$

There is also a need to mention the transition of police institutions, as it differs from any of the above due to its very specific nature. Probably the best example occurred in the early 1990s when many former communist countries in Eastern Europe regained their sovereignty and their own security sectors had to undergo a transition process. The transition of police service from a communist type to democratic police remains an issue in Central Asia and elsewhere. This is almost as great a challenge as rebuilding a new police service from the ground up, and some may see it as a very large scale reform process. However, it is more than an institutional reform since several elements beyond the scope of reform should be addressed, such as the de-politicization of the police, the establishment of civilian oversight and the transformation from a strongly centralized military type to a non-military model designed to be part of the rule of law and not above the law. Such a transition occurs extremely rarely since such a change is always associated with a major change of political course.

No matter the aim and scope of the change, there is a need to 1) conduct a multidimensional assessment, 2) determine the desired structure of the future police, 3) find the means to move the existing police (or start rebuilding from the ground up) towards the end stage police model using measurable benchmarks and 4) compile all envisaged goals and means into a strategic plan and implementation plan.

There are many well written academic publications about the aforementioned procedure, therefore this article will not address this, but rather focus on specific orientation points for designing a new police. All democratic police institutions can be measured against the categories examined in detail below. The author of this article believes that it is useful to compare any existing police or newly designed service against these categories in order to see the possibilities of potential changes ahead. With this in mind, the reader may find answers or at least orientation points when trying to answer the question, "What police do we need?"

\section{Dual/MultiPolicing System versus One Dominant Police Institution}

The best examples of two key cooperating and, at the same time, competing policing institutions within one country are those of France, Italy and Spain and their national police and paramilitary police services, the Gendarmerie, Carabinieri and Guardia Civil, respectively. ${ }^{2}$ This dual system exists in less than a dozen European countries and in

1 The Catalonian Police, Mossos d'Esquadra, developed from the ground up over a period of 22 years. It was established in 1983 and the development of the service concluded in 2005 reaching full scale operational capabilities.

2 It should also be noted that besides the gendarmeries and the national police services there are additional institutionally independent police services such as: city police/ municipality police, regional police, etc. 
many African countries, ${ }^{3}$ where the colonizing state's administration-including the dual police system - and institutions remain as a legacy of colonization. The authority of the police services is divided according to population, where highly populated areas fall under national police authorities and the less inhabited rural areas fall under the gendarmerie type services. Both institutions have full scale capabilities although the parallel capabilities are not equally well developed; some would argue that the gendarmerie is better suited to address large scale, violent public order related matters. Despite the disadvantage of the competing coexistence, the dual system seems a better fit for medium or large countries, especially when the state administration is centralized under the continental type of legal system. Due to institutional competition, checks and balances are better maintained in this type of system; however, most recent European case studies show that it is not worthwhile to establish or maintain a dual policing system in a country with less than 10 million inhabitants. ${ }^{4}$

\section{One Single Police Model versus one One Single Service with Special Police Services}

While there is no dual system on the policing front, the healthy rivalry may be maintained by having one single, dominant police institution surrounded by either 1) other (special) policing institutions with nationwide jurisdiction, such as a counterterrorism service or a high-profile organized crime police service (specialization based approach) or 2) some county/city police institutions may also be competitive police bodies having shared or exclusive police authorities in legally defined areas (territory based approach). In rare cases, there is one single integrated police service without limitation of territorial jurisdiction. However, such a model may be effective only in small territories (smaller island states) where integration is the only reasonable solution to create the most effective service. ${ }^{5}$ Additionally, a highly integrated police service may also be very centralized and concentrated.

3 There are more than 30 countries worldwide with gendarmerie, such as Algeria, Argentina, Benin, Bulgaria, Burkina Faso, Burundi, Cambodia, Cameroon, Central African Republic, Chad, Comoros, Congo, Democratic Republic of Congo, Djibouti, Equatorial Guinea, Egypt, France, Gabon, Gambia, Guinea, Ivory Coast, Jordan, Lebanon, Madagascar, Mali, Morocco, Mauritania, Niger, Romania, Rwanda, Serbia, Senegal, Togo, Tunisia, Turkey and Vatican City.

4 Please see the European example. Among countries with gendarmerie services, by territory and population Portugal is the smallest. Belgium and Austria (both under 10 million inhabitants), in the frame of the police modernization reform program, merged its gendarmerie services into one national police system. The Vatican City Gendarmerie service is 130 strong but due to its small size and unique appearance, this is not viewed as a potential role model.

5 Under the head of the Malta Police Service there are various police branches, including: crime dept., financial crime dept., protective dept., traffic dept., immigration and border control dept., visa office, VIP protection, admin dept., finance dept., forensic science laboratory, etc. the list is not exhaustive. See Malta Police Force Organizational Chart, www.police.gov.mt/ en-us/organisation-chart.aspx (4 November 2013). 


\section{Police Force versus Police Service (Military Type versus Civilian Based Police)}

Often, even practitioners fail to correctly distinguish between the two very different terminologies. Indeed, experts with military background may wish to use the term "Police Force" when they actually mean to describe democratic policing. The difference may appear as only a nuance but it is significant. Unless the "Police Force" approach is preferred for specific reasons, I would argue to use the term "Police Service," since the police is part of the civil administration system. As described, this is not only a terminology issue but rather a subtle cultural interpretation on how the police should be viewed externally. The word "Force" denotes the military, thus when the police is organized it should be separated from military force by many means, both figuratively and literally. It is fascinating to see the police ranking system, which in some countries differs from classical military ranks but not always. Traditionally, many post-communist countries still use military type ranks in their police services.

\section{Reactive versus Reactive \& Preventive Police}

The police service is also part of the more encompassing rule of law sector. It is worthwhile examining how the integration takes place, the role of the supervising authority over the investigating police authority, autonomy in investigations versus directed, dictated course of investigating actions, etc. All should be carefully studied since there are several well-functioning models in this regard. Here, the focus is given to the general police approaches towards crimes. First and foremost, all police services should have an effective criminal investigation skill set in order to fulfill its reactive roles, which come into effect as soon as some crime is detected and investigation must commence. However, society lawfully expects crime and public order related preventive measures. Modern police institutions should be measured and tested against their ability to develop preventive measures. In this segment preventive measures may be limited by two factors: 1) financial and 2) the (challenging) efficiency measuring methods, thus only limited attention is paid to prevention, especially not before the reactive police mechanism is fully developed. In short, capabilities to provide effective and visible preventive measures are clear indicators of a highly developed police service.

\section{Centralized versus Decentralized Police: State Primacy on Policing or Shared Primacy with Regional, Municipal Authorities}

Historically, the first modern police services were not centralized but established in order to serve highly populated, particularly metropolitan areas. ${ }^{6}$ Some services (such as those in the UK and the Netherlands) never reached a centralized model; meanwhile other services (especially following the Soviet model) have been extremely centralized. Of course, in all cases, the type of state administration and the type of legal system

6 One of the first modern police services, the Metropolitan Police, was created by Sir Robert Peel with the implementation of the Metropolitan Police Act, passed by Parliament in 1829. 
should also be closely examined to determine the complexity of the case. Out of the European scope, the U.S. policing system should be noted as a very complex and multitype policing model. There are more than 17,000 police institutions at six different levels; ${ }^{7}$ the scope is extremely large and varied from federal jurisdictions to municipal jurisdictions. Regarding the centralized and partially decentralized models, perhaps the French system should be closely studied as a classical model. The German federal and state level policing model is also interesting as it is a well-balanced and effective combination of some centralized and decentralized models. The current tendencies are showing ambivalent pictures since there are examples of both centralization interest and decentralization trends that deploy and hand over more policing tasks to the municipal level.

\section{One Police Model Including Crime, Public Order and Traffic Pillars versus a Separate Model}

All police services consist of at least two fundamental pillars. The first, public order and traffic services as the high visibility uniformed police service and, second, the criminal investigation service. Both are essential parts and the author of the present article would argue that their proximity is essential in order to achieve effective synergy and close cooperation. However, this is mostly the case of the centralized police system, whilst police services built up on a different philosophy often separate the uniformed and investigative services. Positioning the two pillars close to each other is therefore advisable.

\section{Specialized Police Staffs versus Generalists}

One would expect that in the twenty-first century all modern police services are moving towards specialization, but this is not always the case. For instance, Norwegian police officers are expected to be generalists, meaning that they should possess several police skills and be equipped to answer to all security related calls. This approach seems to be more rarely applied, but nevertheless it is worth studying further. Such a model could work better in a large, less populated country when the police are extremely developed, well trained and with high-tech capabilities.

\section{Community Oriented Police Philosophy and the Latest Trends}

The author of the present essay recognizes that modern community policing is not at all a modern phenomenon since it has long been in existence, for example the UK system. As of today, almost all modern police services (despite the many aforementioned diversifications) have implemented some sort of applied community policing. There is no debate about its existence in modern policing, but rather about how community policing is understood and implemented. Should this be further investigated, the UK and the USA systems would be important case studies. Additionally, in the UK, among different

7 Source: http://discoverpolicing.org/whats_like/?fa=types_jobs (12 September 2013). 
policing trends the latest is "Total Policing." ${ }^{8}$ Meanwhile, in the USA there are several co-existing policing schools, such as "Zero Tolerance," "Problem-oriented Policing" $(\mathrm{POP}),{ }^{10}$ and "Intelligence-led Policing" to mention just a few among many implemented policing trends. ${ }^{11}$

\section{Police to Population Ratio}

The ratio between the total population of a country and the total police staff seems to be an internationally used and objective way of measuring and comparing police services. However, it has to be noted that this is not as exact as it looks. To illustrate this, one should focus a bit on police strength. In some countries the border guard service is treated as an integrated part of the national police service. This is the case of Hungary (as of many other European countries that are members of the Schengen System) and yet the border guard pillar as an integral part of the Hungarian Police Service may falsely skew the total number of police by $15-18 \%$ more. For this reason it is necessary to carry out a careful study of the relevant figures. Some experts may posit that 1:500 is a good ratio, as the North European countries fall under the 1:400 to 680 range, but the ratio of most developed democratic countries tends to fall mostly in the range between 1:250 to $500 .^{12}$

$$
* * *
$$

For limits of space, the article must draw to a close without touching upon other police attributes, such as gender mainstreaming, political/civilian oversight, internal control, police education system. Each of these subjects would require a separate article to discuss the topic fully.

The present essay is by no means exhaustive and all of the points it discusses ought to be further expanded with other substantial elements. Despite this, its author believes that defining the aforementioned nine types of police service may offer sufficient points of orientation towards a better understanding of the variety of existing police services and the different stages of rebuilding, transferring, reforming, or adjusting national police services.

8 The Total Policing has been introduced by Police Commissioner Bernard Hogan-Howe, head of the Metropolitan Police Service, appointed in 2011. The short description is: "A total war on crime, total care for victims, and total professionalism from our staff."

9 This was first introduced by the current New York Police Chief, William Bratton in the mid1990s.

10 Herman Goldstein, Problem-oriented Policing (New York: McGraw-Hill, 1990).

11 Mark Riebling (Editorial Director at the Manhattan Institute for Policy Research), Hard won lessons: the new paradigm - merging law enforcement and counterterrorism strategies (Safe Cities Project, January 2006), www.manhattan-institute.org/pdf/scr_04.pdf (10 October 2013).

12 Used sources: http://europa.eu/about-eu/countries/member-countries; www.interpol.com; http://appsso.eurostat.ec.europa.eu/nui/show.do?dataset=crim_plce\&lang=en\# (18 November 2013). 
THE QUARTERLY JOURNAL

\section{Bibliography}

Goldstein, Herman. Problem-oriented Policing. New York: McGraw-Hill, 1990.

Malta Police Force Organizational Chart., 2013.

Riebling, Mark. Hard won lessons: the new paradigm - merging law enforcement and counterterrorism strategies In Safe Cities Project., 2006. 